\title{
ВТОРИЧНЫЕ КАОЛИНЫ ДЕВОНА ВОРОНЕЖСКОЙ АНТЕКЛИЗЫ НА ПРИМЕРЕ МЕСТОРОЖДЕНИЯ КОЗЫНКА
}

\author{
А. Д. Савко, С. В. Мануковский, А. В. Крайнов, Н. А. Корабельников, А. В. Милаш \\ Воронежский государственный университет \\ Поступила в редакцию 22 мая 2018 г.
}

\begin{abstract}
Аннотация: вторичные каолины развиты в верхнедевонских отложениях, образованных за счет размыва коры выветривания на кристаллических породах докембрия южной части Воронежской антеклизы. Здесь в эрозионно-тектонической депрессии сформировалась мамонская песчанокаолиновая толща (ПКТ), в которой каолины переслаиваются с квариевыми, в том числе каолинистыми, песками, т.е. она представляет собой комплексное минеральное сырьё. Толща развита на территории около $28000 \mathrm{~km}^{2}$, имеет мощность от 10 до первых сотен метров. По долинам рек она залегает вблизи дневной поверхности, на водорозделах мощность перекрывающих пород достигает 200 м. ПКТ сложена породами континентальной, переходной и морской групп фаџий. Первые представлены пролювиально-делювиальными, пролювиальнылми, аллювиальными образованиями различного гранулярного состава, быстро меняющимися как в плане, так и в разрезе, и содержащиии пласты вторичных каолинов. Переходные и морские отложения появляются в восточной части поля развития толщи и содержат органогенные известняки и карбонатные глины. Песчаная часть разреза перспективна на стекольное, формовочное, строительное сырьё. Наличие в ней глинистой примеси дает возможность получить обогащзенный каолин. При неглубоком залегании толщи её можно разрабатывать открытым способом, в случаях большой мощности вскрыши - гидроскважинным. По составу пород ПКТ, их мощностям и глубинам залегания выделены Западный, Центральный и Восточный участки. Наибольшие перспективы нахождения месторождений связаны с Центральным участком, где насыщенность каолинами наибольшая, а в долинах рек они залегают близь дневной поверхности. Авторами выделена мамонская рудная зона развития керамических глин.
\end{abstract}

Ключевые слова: каолин, песчано-каолиновая мамонская толщу, кора выветривания, фаџии, квариевые пески.

\section{SECONDARY KAOLINS OF THE DEVON OF THE VORONEZH ANTECLISE BY THE EXAMPLE OF THE KOZYNKA DEPOSIT}

\begin{abstract}
Upper Devonian sediments formed due to erosion of the weathering crust on Precambrian crystalline rocks of the southern part of the Voronezh anteclise. Here, in the erosion-tectonic depression, the Mamon sand-kaolinic stratum (PCT) was formed, in which the kaolins are interbedded with quartz, including kaolin, sand, i.e. it is a complex mineral raw materials. The thickness is developed on the territory of about 28,000 km2, has a capacity from 10 to the first hundred meters. On the river valleys, it lies near the surface of the day, on the seaweeds, the thickness of the overlapping rocks reaches $200 \mathrm{~m}$. The PKT is composed of rocks of continental, transitional and marine groups of facies. The former are proluvial-deluvial, proluvial, alluvial formations of various granulometric composition, rapidly changing both in plan and in section, and containing layers of secondary kaolins. Transitional and marine sediments appear in the eastern part of the field of development of the sequence and contain organogenic limestones. The sandy part of the cut contains glass, molding, building materials. If clay impurities are present, enriched kaolin can be obtained. With a shallow bedding of the strata, it can be developed in an open way, in cases of high stripping capacity - with a hydro-well. According to the composition of rocks, their thicknesses, depths of occurrence, the Western, Central and Eastern sections are identified. The greatest prospects for finding deposits are associated with the Central site, where the saturation of kaolins is greatest, and in river valleys they lie near the surface of the day. The authors singled out the Mamon ore zone for the development of ceramic clays.
\end{abstract}

Key words: kaolin, sand-kaolin mammon stratum, weathering crust, facies, quartz sands. 
Каолин является важным видом минерального сырья, поскольку широко применяется в производстве огнеупоров, керамики, резины, полимеров, красок, бумаги, стройматериалов и многих других материалов и изделий. На территории Европейской части России нет промышленных месторождений каолинов. Транспортировка сырья с ближайших отечественных месторождений (южноуральских) экономически невыгодна. Россия, в силу этих обстоятельств, вынуждена импортировать обогащенный каолин, в основном, из Украины, уровень добычи которого там более чем на порядок превышает российский. В связи с государственной политикой, направленной на импортозамещение, необходимость создания конкурентоспособной отечественной отрасли по добыче и производству каолинов особенно актуальна. Возрастает интерес ко всем каолинитсодержащим геологическим объектам и, в частности, к мамонской толще, развитой в южной части Воронежской антеклизы.

Собственно геологии мамонской толщи посвящен целый ряд опубликованных и фондовых материалов. Рассматриваемые отложения впервые выделены как самостоятельное геологическое тело А. А. Дубянским под названием «мамонские слои» [1]. Термин «мамонская толща» ввел Д. Н. Утехин [2], датируя её возраст от раннефранского до озерского $\left(\mathrm{D}_{3} \mathrm{f}_{1}-\mathrm{fm}_{3}\right)$. Наряду с этим, как в научной литературе, так и в производственных отчетах, широко применяется и термин «песчано-каолиновая толща». Не содержащей фаунистических остатков ПКТ на протяжении всего периода изучения приписывался не однозначный возрастной диапазон. А. А. Дубянский, выделенные им мамонские слои, вначале определил как возрастные аналоги петинских слоев [1], а затем относил их к нижнему карбону [3]. Палинологические исследования девонских отложений Воронежской антеклизы позволили Л.Г. Раскатовой установить возрастные границы формирования ПКТ и расчленить ее на восточном склоне антеклизы до горизонтов. Нижняя граница толщи вначале была определена ею как воронежский горизонт [4], а затем «опущена» до петинского [5]. На современном этапе возрастные границы мамонской толщи принимаются по этому автору как начало формирования - петинское, окончание - кудеяровское время $\left(\mathrm{D}_{3} \mathrm{f}_{3}-\mathrm{fm}_{3}\right)$.

Толща залегает на глубинах от первых метров в речных долинах до 200 и более метров на водоразделах и сложена преимущественно продуктами переотложения каолиновых кор выветривания (КВ) на породах кристаллического фундамента. Разрез толщи представлен континентальными глинисто-песчаными образованиями, на крайнем востоке своего распространения переходящими в песчано-глинистые морские отложения с тонкими прослоями органогенных известняков и глин.

В 2008 г. А. Д. Савко, С. В. Мануковский, Л. Т. Шевырев в обобщающей монографии показали распространение, геологическое строение и вещественный состав мамонской толщи [6]. ПКТ представляет гео- логическое тело, сложенное породами кварцкаолинового состава и приуроченное к эрозионнотектонической депрессии. Её выполняют аллювиальные, пролювиально-делювиальные, а на крайнем юго-востоке и морские образования, мощности которых нарастают с запада на восток и с юга на север к центральным частям депрессии. На основе серии карт (палеогеоморфологической, литологофациальных, структурных, изопахит) были выделены перспективные площади с прогнозными ресурсами каолинитовых глин и песчано-гравийных смесей.

ПКТ развита на территории юга Воронежской и, частично, востока Белгородской, севера Ростовской и северо-запада Волгоградской областей (рис. 1). Общая площадь её распространения около 28000 км $^{2}$ и четко разделяется на 3 участка: Западный, Центральный и Восточный. Первый протягивается от пограничных районов Курской и Белгородской областей до г. Павловска на 280 км при ширине полосы от 25 до 60 км. Он приурочен к юго-западному склону антеклизы и отстоит от ее оси на 20-40 км к юго-западу. Центральный участок располагается к востоку от долготы г. Павловска до г. Калач. Его длина и ширина порядка 60 км каждая. Восточный участок прослеживается восточнее долготы г. Калач. Его ширина вдоль склона антеклизы нарастает от 70 до 200 км.

ПКТ с резким угловым и стратиграфическим несогласием залегает на образованиях кристаллического фундамента, а также на породах ястребовской, чаплыгинской, саргаевской и семилукской свит нижне- и среднефранских подъярусов верхнего девона. На Западном участке песчано-каолиновая толща ложится, преимущественно, на докембрийские образования. На Центральном и Восточном она последовательно, с юга на север, перекрывает кристаллический фундамент докембрия, чаплыгинские, саргаевские и семилукские отложения. На докембрийских образованиях толща залегает узкой полосой (15-30 км) на крайнем юго-западе (к юго-востоку от г. Богучара) (рис. 2). На большей части Центрального и Восточного участков отложения ПКТ подстилаются чаплыгинскими глинами. Перекрывается мамонская толща разновозрастными отложениями - от верхнефаменских до голоценовых. На присводовых участках антеклизы она находится под мезозойскими, а на склонах - палеозойскими образованиями.

Вариации мощности песчано-каолиновой толщи от 10 м до первых сотен метров определяются, вопервых, структурным положением различных ее участков, и, во-вторых, либо «консервацией» полных разрезов при бронировании толщи перекрывающими нижнетурнейскими терригенно-карбонатными образованиями, либо размывом в мезокайнозойское время. Фациальный анализ и анализ распределения мощности позволяют предполагать, что во время накопления мамонской толщи изучаемый регион представлял собой единую моноклиналь, полого наклонную в северном и северо-восточном направлениях и осложненную изохронным Павловским поднятием. На распределении 


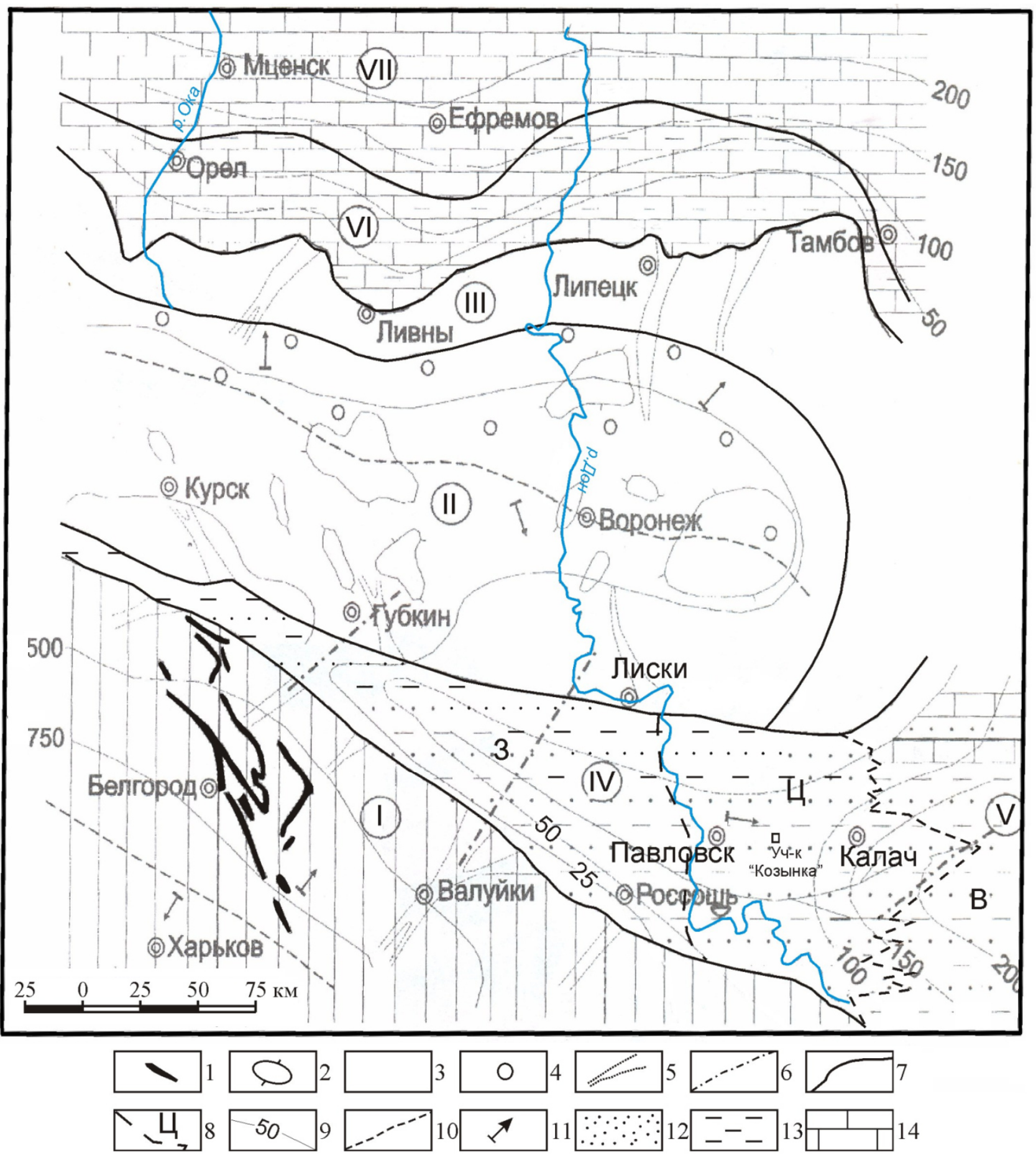

Puc. 1. Схематическая литолого-палеогеоморфологическая карта позднефранского-среднефаменского времени на территории Воронежской антеклизы с использованием материалов [7]. Морфогенезис рельефа (римскими цифрами): $I-$ пенеплен слаборасчлененный; равнины: $I I$ - эрозионно-денудационная, $I I I$ - прибрежно-морская денудационно-аккумулятивная, $I V-$ аллювиальная, $V$ - дельтово-лагунная, $V I$ - прибрежно-морская, $V I I$ - мелководно-морская; элементы рельефа: 1 - гряды и останцы литолого-структурные, 2 - поднятия, 3 - области размыва, 4 - карстовые полости, 5 - речные долины, 6 - разломы, 7 - границы распространения равнин, 8 - участки развития мамонской толщи: 3 - Западный, $Ц$ - Центральный, $B$ - Восточный, 9 - изопахиты позднефранских-фаменских отложений, 10 - линия водораздела, 11 - направление сноса; породы: 12 - пески, алевриты, 13 - глины, 14 - карбонатные породы.

мощностей, кроме их увеличения вниз по склону антеклизы, сказалось влияние Павловского поднятия, где они уменьшены [8]. В южной части распространения мощность мамонской толщи возрастает в целом в севе- ро-восточном направлении, простирание изопахит такое же, как и на юго-западном склоне антеклизы.

Моноклинальный план распространения толщи осложнен несколькими речными палеодолинами, 


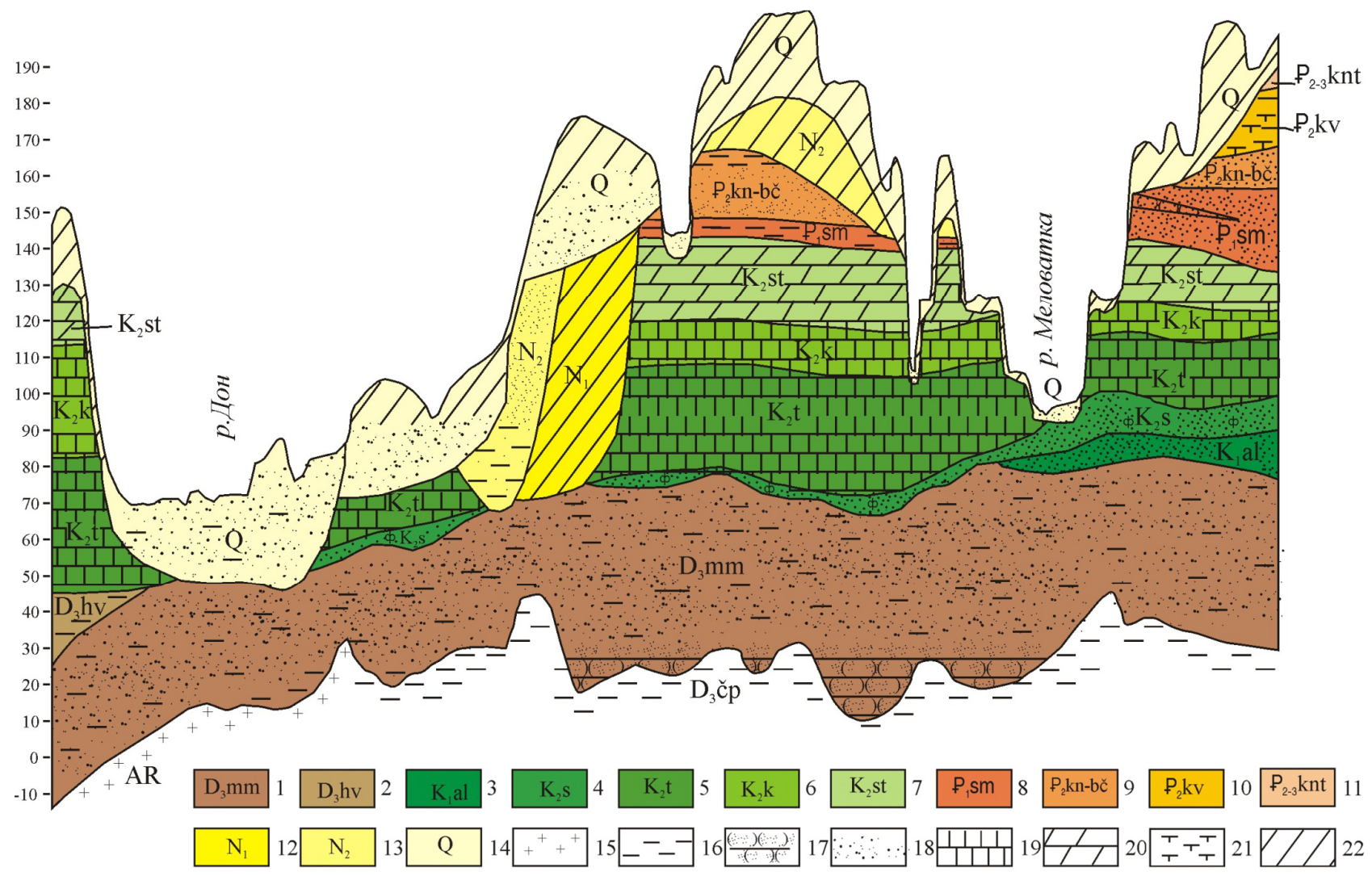

Puc. 2. Геологический разрез по линии Дон-Меловатка: 1-12 - стратиграфические подразделения: 1 - мамонская толща, 2 хованский горизонт, 3 - альбский, 4 - сеноманский, 5 - туронский, 6 - коньякский, 7 - сантонский ярусы, 8 - сумская серия, 9 каневская-бучакская, 10 - киевская, 11 - кантемировская свиты, 12 - миоцен, 13 - плиоцен, 14 - четвертичная система; 15-22 породы: 15 - граниты, 16 - глины, 17 - песчаники, 18 - пески, 19 - мел, 20 - мергель, 21 - известковистые глины, 22 - суглинки.

в которых мощность аллювиальных образований на 15-25 м больше по сравнению с их мощностью на смежных водоразделах.

Мощность перекрывающих мамонскую толщу отложений очень изменчива. Она зависит от положения толщи на той или иной части склонов антеклизы и от рельефа дневной поверхности. Первый признак является региональным, определяющим ситуационный план изопахит вскрыши, второй позволяет выделить благоприятные участки в долинах рек, где мощность перекрывающих ПКТ отложений минимальна. Наибольшая дифференциация в значениях мощности перекрывающих толщу пород отмечается для Западного участка, где кровля мамонской толщи залегает на глубинах от 40 до первых сотен метров.

Интенсивный эпейрогенез Павловского поднятия, приуроченного к Центральному участку развития ПКТ, в девонское и постдевонское время привел к тому, что залегающая на его юговосточном и восточном склонах мамонская толща оказалась высоко приподнятой и перекрывающие ее верхнедевонские образования в меловой период были размыты. Неотектонические поднятия процесс размыва усилили еще больше. Меловые отложения были прорезаны руслами рек, и кровля песчано-каолиновой толщи в долинах Дона и его притоков оказалась перекрыта только четвертичными аллювиальными породами. Такие участки наиболее перспективны на поиски месторождений с разработкой открытым способом. Они располагаются на площади листа M-37-XVII (Павловск).

На Восточном участке развития ПКТ мощность перекрывающих отложений резко возрастает в южном и восточном направлениях, достигая первых сотен метров на юго-востоке Воронежской и северо-западе Волгоградской областей. Здесь можно прогнозировать месторождения каолинов и песчано-гравийных смесей с отработкой гидроскважинным способом.

В фациальном плане песчано-каолиновая толща сложена породами континентальной, переходной и морской групп фаций.

В пределах площади распространения мамонской толщи Западного участка отмечается 16 фациальных зон, представленных континентальными образованиями [6]. Такая пестрота объясняется наличием пролювиально-делювиальных, пролювиальных, аллювиальных отложений различного состава, их сильной изменчивостью, как в плане, так и в разрезе. Характерно резкое преобладание обломочных пород - от алевритов до разнозернистых песков, иногда гравийников. Каолины развиты крайне незначительно, поэтому перспективы на наличие их месторождений 
крайне незначительны.

В пределах Центрального участка в течение всего мамонского времени формирование пород осуществлялось в континентальных условиях. В составе ПКТ резко преобладают разнозернистые пески, в разной степени каолинистые. Пески местами превращены в слабо сцементированные каолином песчаники. Их цвет белый от присутствия каолина, реже желтоватый. Отдельные слои песков достигают мощности 5-7 м. Глины, в подавляющей своей массе состоящие из каолинита и содержащие в различных количествах алевропесчаную примесь, образуют линзы мощностью от первых миллиметров до 5-10 м и протяженностью первые десятки, реже сотни метров. Для континентальных пород обычно характерна невысокая степень сортировки, хотя встречаются хорошо сортированные кварцевые прослои с гравийно-песчаным материалом, крайне дефицитным в ЦентральноЧерноземном районе в связи с широко развернувшимся строительством жилья, промышленных сооружений, автомобильных и железных дорог. Мамонская толща является комплексным сырьем, поскольку при гидроклассификации её пород возможно получение не только каолина, но и песков различного гранулярного состава и назначения.

По мере удаления от приподнятых частей антеклизы, в северо-восточном и восточном направлениях (на Восточном участке развития ПКТ), в мамонской толще появляются вначале переходные, а затем - морские фации. При этом доля континентальных отложений снижается, возрастает количество прослоев морского генезиса. В крайней юго-восточной части изучаемой территории в разрезе преобладают уже породы прибрежно-морских и переходных фаций. На до- лю континентальных приходится 10-20\%. Отложения, соответствующие стратиграфическому объему пород мамонской толщи, могут расчленяться на отдельные горизонты: петинский, воронежский, евлановский, ливенский. Верхняя часть толщи, где и концентрируются самые удаленные от свода антеклизы континентальные фации, разделяется менее дробно на нижний и средний фамен. Эта часть, мощность которой изменяется от 38 м до нуля, представлена континентальным комплексом, объединяющим переслаивание разнозернистых песчаников и каолинитовых глин. Общая мощность толщи на Восточном участке достигает максимального значения - 220 м. Нижняя и средняя части мамонской толщи сложены пачкой неравномерного переслаивания карбонатных глин и известняков, насыщенных остатками фауны брахиопод, остракод, кораллов, криноидей, мшанок, гастропод, рыб.

Таким образом, наиболее перспективной для поисков месторождений вторичных каолинов является неглубоко залегающая верхняя часть ПКТ, представленная континентальным комплексом пролювиальноделювиальных, аллювиальных и озерно-болотных образований Центрального участка, где отмечаются относительно мощные пласты глин и каолинитсодержащих песков. В работе [6] выделены прогнозные участки для постановки на поиски каолинов разведочных работ, которые привели к открытию месторождения с авторскими запасами в десятки миллионов тонн.

Типичный разрез такого месторождения, расположенного западнее г. Калач на участке Козынка (см. рис. 1), приведен на рис. 3. Здесь на оценочной площади, разведанной по категориям $\mathrm{C}_{1}$ и $\mathrm{C}_{2}$, в ПКТ наблюдается переслаивание двух типов полезных ископаемых: кварцевых каолинитсодержащих песков и

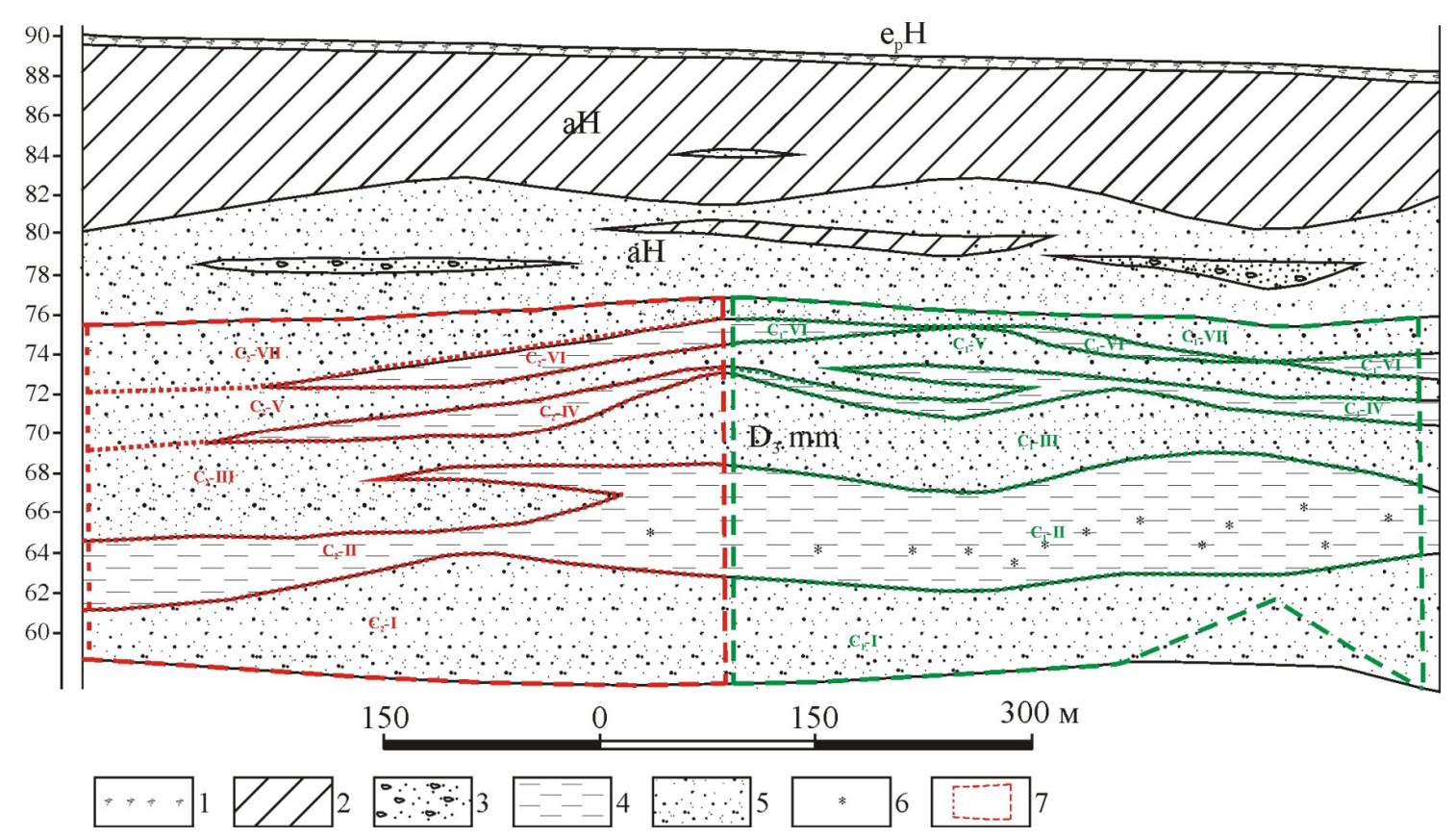

Puc. 3. Разрез участка Козынка: 1 - почвенно-растительный слой, 2 - суглинок, 3 - песок разнозернистый с гравием, 4 - глина, 5 - песок, 6 - ожелезнение, 7 - контуры подсчетов запасов. 


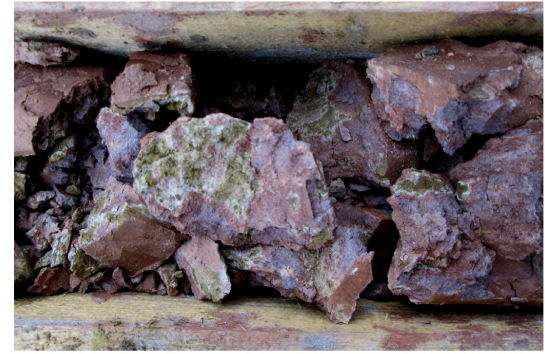

a

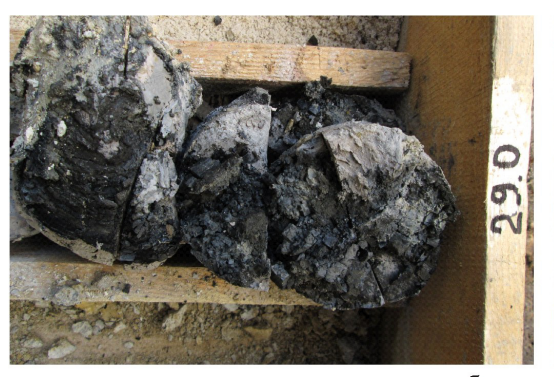

6

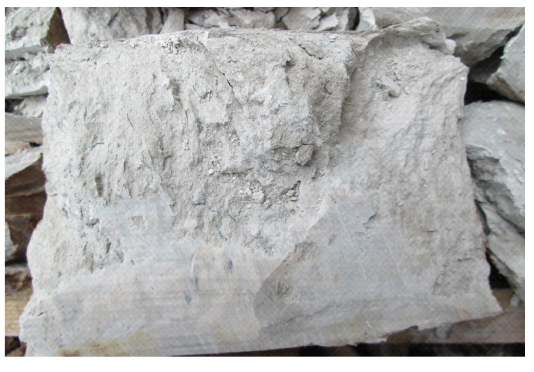

B

Puc. 4. Фото каолинитовых глин мамонской толщи: $a$ - пролювиальные пестроцветные, сильно ожелезненные за счет гематита и лимонита; $\sigma$ - озерно-болотные, углефицированные; в - пойменно-старичные серые.
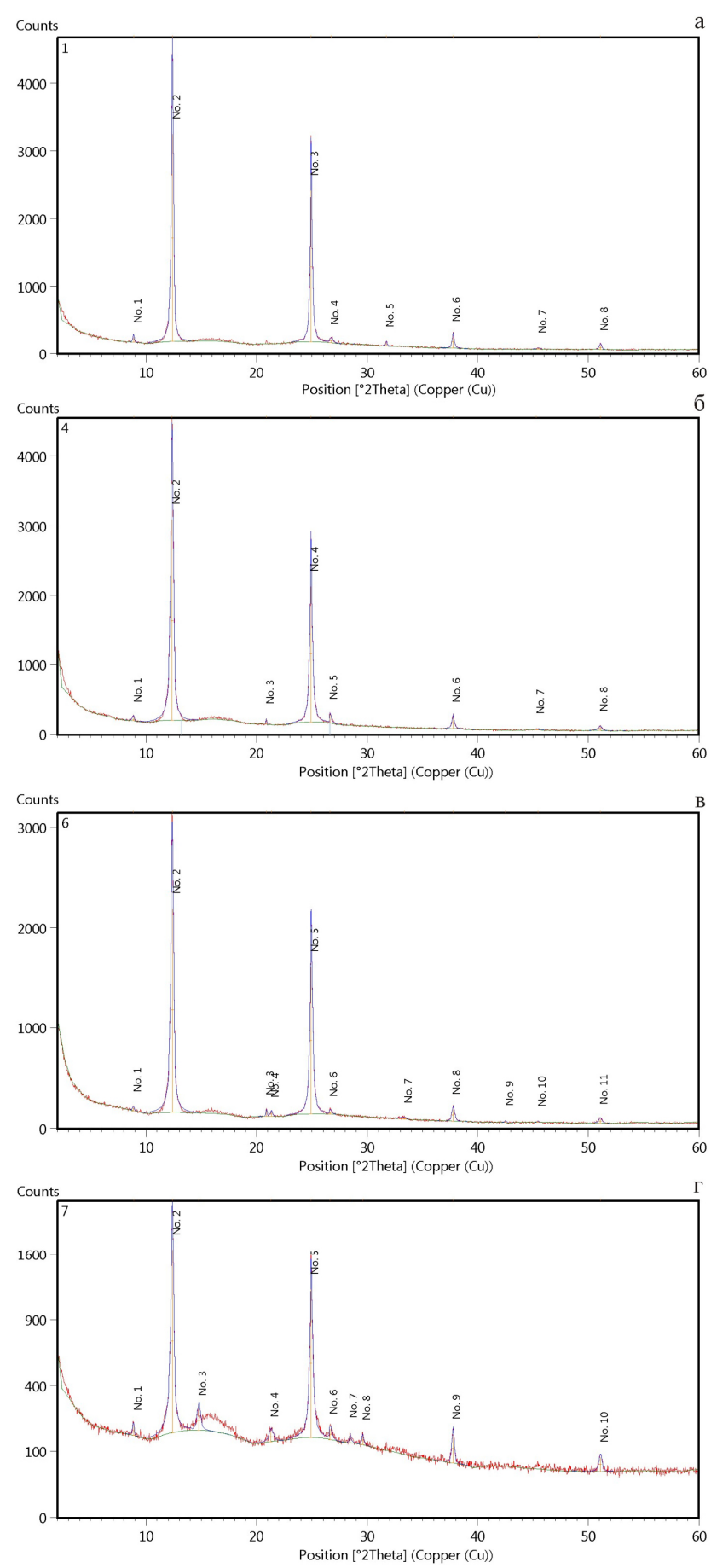

каолинитовых глин. Снизу вверх по разрезу выделяются 7 горизонтов полезных ископаемых: I кварцевые каолинитсодержащие пески; II - каолинитовые глины; III - кварцевые каолинитсодержащие пески; IV - каолинитовые глины; V - кварцевые каолинитсодержащие пески; VI - каолинитовые глины; VII - кварцевые каолинитсодержащие пески. Кварцевые каолинитсодержащие пески рассмотрены в работе [9].

Отмеченные горизонты (тела полезных ископаемых) выдержаны по простиранию и прослеживаются на оценочной площади, они увязываются на территории изученной как по категории $\mathrm{C}_{1}$, так и $\mathrm{C}_{2}$. На оценочной площади участка Козынка среди вскрытых тел полезных ископаемых наибольшая мощность отмечается для нижних горизонтов. Средние мощности слоёв каолинитовых глин II 4,36 м, IV - 1,36 м, VI - 0,9 м.

Глины приурочены к озерно-болотным или аллювиальным пойменно-старичным фациям. В нижней части разреза они пролювиальные пестроцветные (рис. 4a). Залегающие выше разности озерно-болотные серые, темно-серые, сильно гумусированные, алевритистые, жирные на ощупь, с раковистым изломом, с автохтонными растительными остатками (рис. 4б), часто углефицированными и пиритизированными. В них отмечаются неясная волнистая текстура и пятнистая окраска за счет неравномерного распределения гумуса. Пойменно-старичные глины светло-серые до серых (рис. 4в), алевритистые, в различной степени запесоченные, жирные на ощупь, с раковистым изломом, редкими аллохтонными УРО и присыпками светло-серого песка по плоскостям напластования. Содержат прослои мелкозернистых кварцевых песков мощностью от 0,2-0,5 до 20-30 см.

По результатам рентгеноструктурного анализа глинистой фракции, описанных литотипов $<0,005$ мм (дифрактометр Empyrean B.V. PANalytica), coдержание каолинита в ней 98,5-99,5 \% (рис. 5 а-г).

Puc. 5. Дифрактограммы глин месторождения Козынка: $a-$ из разновидности серых глин; $\sigma$ - из разновидности темно-серых гумусированных глин; $в$ - из разновидности пестроцветных (вишневых) глин; 2 - из разновидности пестроцветных (табачных) глин. 
Лишь в одной пробе, относящейся к разновидности пестроцветных глин, 1,5\% приходится на иллит, в остальных пробах содержание доли иллита среди глинистых минералов еще меньше - около 0,5. Во всех случаях на дифрактограммах отмечается присутствие тонкодисперсного кварца. В окрашенных глинах фиксируются рефлексы лепидокрокита, гетита, гематита, являющиеся вредными примесями (рис. 5 в, 5 г). Содержание этих минералов в сумме колеблется от 0,5 до $1 \%$.

Вблизи южных границ распространения мамонской толщи, где она залегает на КВ кристаллического фундамента, каолинит обладает довольно совершенной структурой: на большинстве дифрактограмм разрешен дублет, которому соответствуют межплоскостные расстояния 4,18 А и 4,13 $\AA$ [10]. Но уже в районе участка Козынка, на удалении 60 км от источника сноса, дублет разрешен только на очень малой части дифрактограмм. В подавляющем же большинстве случаев рефлексов серии hk не наблюдается, а каолинит диагностируется обычно по отражениям 001 и 002 с интенсивностью 100 и $70 \%$, что свидетельствует о невысокой степени совершенства кристаллической структуры минерала. Этот вывод весьма важен, поскольку каолинит с неупорядоченной структурой имеет пониженные значение температуры плавления и повышенный интервал спекаемости, что благоприятно сказывается на качестве и стоимости керамических изделий $[11,12]$.

Изучение глинистых пород показало, что по данным растровой электронной микроскопии для каолинита из пестроцветных глин нижней части мамонской толщи (рис. 6а) размер частиц каолинита колеблется от 0,2-0,3 мкм до 2,0х3,5 мкм, обычно менее 1 мкм. Гексагональные грани, характерные для неизмененного (первичного) каолинита КВ [10], встречаются редко. Пластинчатые частички минерала повсеместно имеют сглаженные (обломанные) в процессе переноса и вторичного переотложения формы. Грани пластинок обычно имеют неровные контуры, часто с волнистыми корродированными краями. В темно-серых гумусированных глинах преобладают частицы размером 0,3-0,45 мкм (рис. 6б). Наряду с «окатанными» и бесформенными пластинками минерала отмечается значительное количество кристаллов с характерным габитусом в виде целых шестиугольных табличек (рис. 6 в). Это может быть объяснено новообразова- нием каолинита в озерно-болотных условиях, как это показано в работе [10].

В наиболее распространенных светло-серых каолинах размер частиц каолинита колеблется в пределах 0,3-0,7 мкм при их толщине в его сотые доли. Такие размеры определяют низкую и среднюю степень дисперсности породы. Кристаллы с гексагональным габитусом практически отсутствуют, изредка в пластинках отмечается одна-две грани минерала. Всё это свидетельствует о преобладающих процессах дробления и измельчения кристаллов каолинита при переносе их из КВ к бассейнам седиментации.

Каолинитовые глины различны по качеству. Два верхних горизонта (IV, VI) близки по внутреннему строению и качеству полезного ископаемого. Это каолинитовые глины от светло-серых до серых, от слабо алевритистых до алевритовых, в различной степени запесоченные, иногда до прослоев песка, с раковистым изломом и редкими растительными остатками. Средневзвешенное значение выхода обогащенного каолина (фракция <63 мкм) достаточно выдержано - 80,41$81,37 \%$. Средневзвешенное содержание оксидов, определяющих керамические свойства каолина (в \%): $\mathrm{Al}_{2} \mathrm{O}_{3}$ -31,81-32,44; $\mathrm{Fe}_{2} \mathrm{O}_{3}-1,57-2,15 ; \mathrm{TiO}_{2}-1,42-1,45$.

По классификации сырья для керамической промышленности [13] эти глины относятся к группам основных огнеупорных (1655-1672 C) со средним содержанием красящих оксидов, низко- и средне дисперсным (средневзвешенное содержание по блокам фракции < 1 мкм 35,77-42,08 \%); умеренно пластичным (число пластичности 8,26-10,15); с умеренной механической прочностью на изгиб (2,58-3,22 МПа); высокотемпературного спекания (1507-1520 С); сильно спекающимся (с водопоглощением 1,62-1,73\% без пережога). Эти глины по ТУ 1512-003-10612023-15 «Глина огнеупорная Латненского месторождения» [14] можно использовать в качестве огнеупорных глин. Они соответствуют маркам ЛТ-ЗЖ, ЛТ-КЖ, ЛТУ1. В слое IV качество глин повышается до марок ЛТ-3С и ЛТ-3Т.

Глины нижнего (II) горизонта отличаются от вышележащих не только повсеместным распространением и значительной мощностью, но и внутренним строением пласта и качеством вскрытых в нем полезных ископаемых. Помимо разновидности светло-серых,

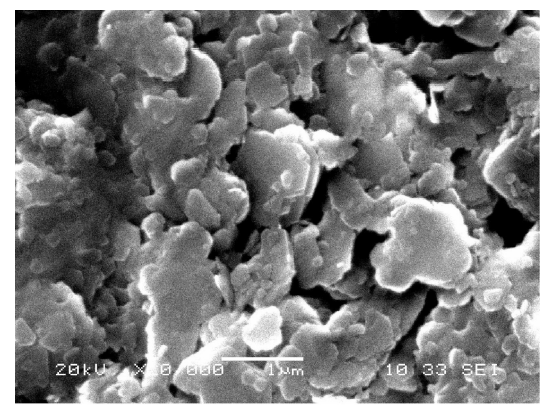

a

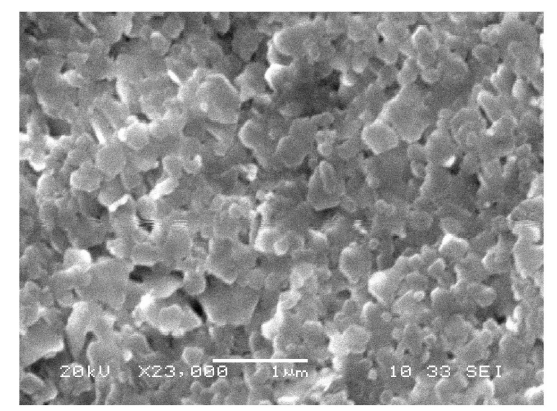

б

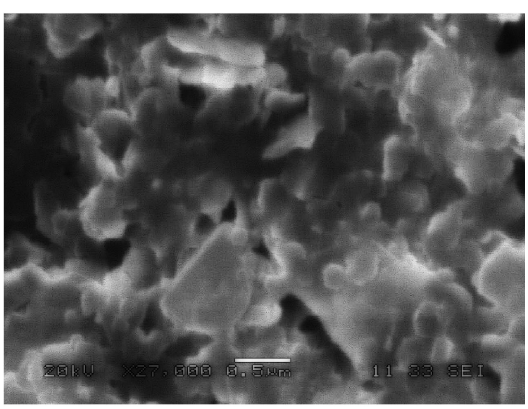

B

Puc. 6. Каолиниты мамонской толщи: $a$ - из пестроцветных глин в нижней части; $\sigma$ - из темно-серых гумусированных глин в нижней части мамонской толщи; в - серых глин в кровле. РЭМ JSM 6380 LV, аналитик к. г.-м. н. С. М. Пилюгин. 
алевритистых каолинитовых глин, характерных для верхних горизонтов, здесь в разрезах всех скважин отмечаются пестроцветные разности. Это - каолинитовые глины, кирпично-красного, вишневого, сиреневого, табачно-зеленого, охристо-желтого цвета, в различной степени ожелезненные (за счет гематита, лимонита), часто - с брекчиевидной текстурой. Кроме отмеченных двух разновидностей глин, в нижнем горизонте встречаются также темно-серые «чистые» (с низким содержанием алевритистых фракций), тонкодисперсные, каолинитовые глины; а также - разновидность темно-серых до черных, сильно гумусированных каолинитовых глин, с прослоями углефицированных разностей, с включениями пирита.

Литологические особенности глин этого слоя определяют отличные от вышележащих каолинов значения химического состава и физико-механических показателей каолинов. Средневзвешенное значение выхода обогащенного каолина (фракция < 63 мкм) - 84,27-84,43\%, содержание оксидов, определяющих керамические свойства каолина, несколько хуже за счет влияния на эти параметры ожелезненных глин. Содержание глинозема снижается $\left(\mathrm{Al}_{2} \mathrm{O}_{3}-30,16-30,39 \%\right)$, а красящих оксидов возрастает $\left(\mathrm{Fe}_{2} \mathrm{O}_{3}-4,21-\right.$ 4,39; $\left.\mathrm{TiO}_{2}-1,42 \%\right)$.

Эти глины можно использовать в качестве формовочных (ГОСТ 322693) [15] и огнеупорных (ТУ 1512-00310612023-15) [14].

Каолин обогащенный из каолинитсодержащих песков также является полезным ископаемым. Качество обогащенного каолина заметно выше, чем качество каолина в собственно каолинитовых горизонтах. Это проявляется, прежде всего, в более благоприятном химическом составе [9].

Наличие месторождения вторичных каолинов позволяет пересмотреть минерагеническое районирование территории листа масштаба 1:1000 000 М-37 (Воронеж). На основании интерпретации работ по ГДП-200 листа М-37-XVII (Павловск), проведенных в начале XXI века, а также изучении Объяснительной записки к геологической карте масштаба 1:1000000 листа M-37 (Воронеж) в пределах этого листа нами выделена Мамонская минерагеническая зона развития керамических глин (рис. 7). Ее границы проводятся по распространению ПКТ. В пределах минерагенической зоны, в центральной ее части выделен ПавловскКалачский рудный район, как наиболее благоприятный для выявления месторождений каолиновых глин. Рудный район включает в себя Козынский рудный узел. Он расположен в восточной части листа М-37XVII (Павловск) и в западной части листа M-37-XVIII (Калач) выявлен Козынский рудный узел (рис. 7) и объединяет в себе перспективные участки, рассмотренные в работе [6], для которых характерна небольшая мощность вскрышных отложений и выявленное месторождение Козынка. Граница рудного узла обоснована распространением нерасчлененных аллювиальных отложений, а также пойменных и старичных. Для них характерно высокое содержание каолинита от $50 \%$ до $90 \%$ [6].

Таким образом, разведочными работами в Калаче-

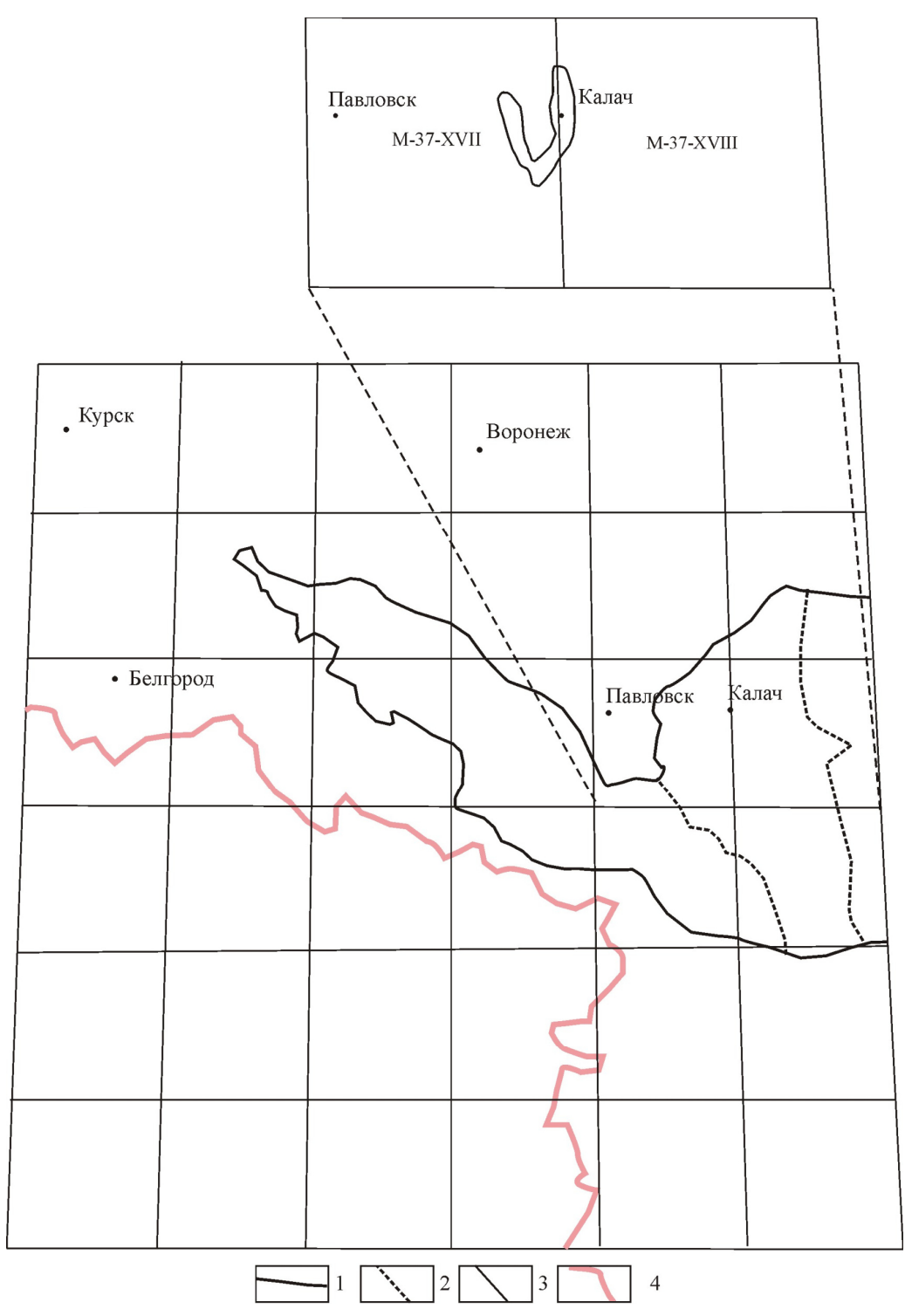

Puc. 7. Предлагаемая схема минерагенического районирования листа $1: 1000000$ М-37 (Воронеж) на каолиновое сырье: 1 - граница Мамонской рудной зоны, 2 - граница Павловск-Калачского рудного района, 3 - граница Козынского рудного узла, 4 - граница Воронежской области. 
евском районе Воронежской области открыто среднее месторождение Козынка вторичных каолинов и кварцевых песков [9], в том числе с различным содержанием глинистой примеси, из которой возможно получение обогащенного каолина. Вмещающие кварцевые пески являются ценным стекольным, формовочным и строительным (песчано-гравийные смеси) попутно добываемым полезным ископаемым. Технологическими испытаниями определена пригодность каолинов в качестве огнеупорного и тугоплавкого минерального сырья для керамических изделий различного назначения. Общие авторские запасы каолинов по категориям $\mathrm{C}_{1}+\mathrm{C}_{2}-$ более 10 млн т, по $\mathrm{P}_{1}-8,6$ млн т; песков по $\mathrm{C}_{1}+\mathrm{C}_{2}-20,8$ млн т, по $\mathrm{P}_{1}-37$ млн т.

Учитывая широкое развитие мамонской толщи на большой территории, её значительную мощность, возможности раздельного получения путем гидроклассификации ценных керамического, стекольного, формовочного и строительного сырья, открываются большие возможности поисков новых месторождений в ПКТ. В пределах Центральной зоны разрабатываются месторождения строительного камня из гранитов и палеогеновых песчаников, бентонитовых глин, мелов, кирпичного сырья, разведаны месторождения медноникелевых руд. Существуют реальные возможности открытия залежей базальтов для получения ценного балластного щебня и каменного литья, аморфного кремнеземистого сырья, графита. На рассматриваемой территории имеются благоприятные экономические возможности. Они включают развитую инфраструктуру, избыток рабочей силы, коммуникации (железная и асфальтированные дороги, пристани на р. Дон, линии электропередач, газопровод), мягкий климат. Всё это позволяет создать на рассматриваемой территории зону ускоренного экономического развития.

Исследование выполнено при финансовой поддержке РФФИ в рамках научного проекта № 18-3500115

\section{ЛИТЕРАТУРА}

1. Дубянский, А. А. Новые данные по геологии Курской и Воронежской областей / А. А Дубянский // «Тр. Воронежск.
СХИ». - Воронеж, 1940. - $146 \mathrm{c}$

2. Утехин, Д. Н. Что такое мамонские слои девона? / Д. Н. Утехин // Тр. межобл. геол. совещ. по геологии и минеральным ресурсам ЦЧО. - Воронеж. - 1962. - С. 68-73.

3. Дубянский, А. А. Песчано-каолиновая толща в озерскохованских и визейских отложениях на юго-востоке Воронежской антеклизы / А. А. Дубянский, Э. В. Косцова // Вестн. МГУ: Геология. - 1967. - № 3. - С. 51-67.

4. Раскатова, Л. Г. О возрасте песчано-каолиновой (мамонской) толщи юго-восточного склона Воронежской антеклизы по данным спорово-пыльцевого анализа / Л. Г. Раскатова // Труды геологического совещания по проблемам изучения Воронежской антеклизы. - Воронеж. - 1966. - С. 272-290.

5. Раскатова, Л. Г. Палинологическая характеристика фаменских отложений центральных районов Русской платформы / Л. Г. Раскатова. - Воронеж: Изд-во ВГУ, 1973. - 174 с.

6. Савко, А. Д. Литология и полезные ископаемые мамонской песчано-каолиновой толщи Воронежской антеклизы / А. Д. Савко, С. В. Мануковский, Л. Т. Шевырев // Труды научно-исследовательского института геологии Воронеж. гос. унта. - Вып. 53. - 2008. - 112 с.

7. Окороков, В. А. Литология фаменских отложений Воронежской антеклизы / В. А. Окороков, А. Д. Савко // Воронеж: Воронежский госуниверситет, 1998. - 124 с.

8. Тектоника восточной части Воронежского кристаллического массива и его осадочного чехла / Г. И. Раскатов [и др.] // Воронеж: Изд-во ВГУ, 1976. - 120 с.

9. Мамонская толща - источник получения стекольного, формовочного и строительного песчаного сырья, обогащенного каолина / С. В. Мануковский [и др.] // Вестн. Воронеж. гос. унта. Сер.: Геология. - 2018. - №1. - С. 58-66.

10. Савко, А. Д. Эпохи корообразования в истории Воронежской антеклизы / А. Д. Савко. - Воронеж : Изд-во Воронежс. ун-та, 1979. - 119 с.

11. Савко, А.Д. Керамические глины ЦентральноЧерноземного района / А.Д. Савко, А.В. Крайнов - Труды научно-исследовательского института геологии Воронежского государственного университета. - Вып. 88. - Воронеж: Изд-во ВГУ, 2015. - 109 с.

12. Минерагения аптских отложений Воронежской антеклизы. Статья 1. Огнеупорные и керамические глины / А.Д. Савко [и др.] // Вестн. Воронеж. гос. ун-та. Сер.: Геология. - 2011. - №2. C. $116-136$.

13. ГОСТ 9169-75. Сырье глинистое для керамической промышленности. Классификация. - М., 1975. - 13 с.

14. ТУ 1512-003-10612023-15. Глина огнеупорная Латненского месторождения. - Воронеж, 2015. - 3 с.

15. ГОСТ 3226-93. Глины формовочные огнеупорные. Общие технические условия. - Минск, 1994. - 9 с.

Voronezh State University

Savko A. D., Head of the Historical Geology and Paleontology

Department, doctor of the Geological and Mineralogical Sci-

ences, Professor, Celebrated Geologist of Russia

E-mail: savko@geol.vsu.ru; Тел.: +7(473) 220-86-34

Manukovsky S. V., Candidate of the mineralogical and geological sciences, leading scientific associate of the Science-and-

Search institute of Geology

E-mail: manukovsky@inbox.ru; Tel.: 8 (473) 222-65-12

Krainov A. V., the master engineer of Scientific Research Institute of Geology

E-mail: aleksey_vsu_geo@mail.ru; Tel.: 8-952-548-47-72

Korabel'nikov N. A., Assistant of chair of Hydrogeology, Engineering Geology and Geoecology

E-mail: gidrogeol@mail.ru; Tel.: 8(473)220-89-80

Milash A. V., the lead engineer of Scientific Research Institute of Geology.E-mail: pirit86@yandex.ru; Tel.: 8-903-030-51-47 